\title{
The reduction of human development gap in origin and new regency in Eastern Indonesia
}

\author{
Jihad Lukis Panjawa ${ }^{1 *}$ and Bhimo Rizky Samudro² \\ ${ }^{1}$ Universitas Tidar, Magelang, Indonesia \\ 2Universitas Sebelas Maret, Surakarta, Indonesia \\ *Correspondence email: jipanjawa@untidar.ac.id
}

\section{ARTICLE INFO}

- Research Article

Article History

Received 30 November 2020

Accepted 5 January 2021

Published 1 April 2021

\section{Keywords}

economic growth; decentralization; human development; poverty; regional status

\section{JEL Classification} H30; I32; 015

\begin{abstract}
Inequality still becomes a popular issue in the establishment of developing countries. Aside from income inequality, human development inequality is considered as an interesting topic for further study, in terms of resuming the solution. The purpose of this study is to identify the human development gap between origin and new regencies in Eastern Indonesia as well as the determinant. This study uses a positivist perspective with a deductive approach. Secondary data with cross-section types are used in this study, covering regencies and cities in Eastern Indonesia. This study uses the econometrics methodology and regression analysis with a dummy variable. The results showed that there were differences in human development index between origin and new regencies in Eastern Indonesia. The human development index in the new regency is lower than in the origin regency. The results support the Myrdal's Theory, which explains the gap in human development disparities among regions due to the significant backwash effects. Fiscal decentralization has a role in reducing the gap in human development in origin and new regencies, yet insignificant for the economic growth. Poverty lowers the impact on increasing human development in the origin regencies but does not occur in the new regencies.
\end{abstract}

To cite this article: Panjawa, J. L. \& Samudro, B. R. (2021). The reduction of human development gap in origin and new regency in Eastern Indonesia. Journal of Socioeconomics and Development, 4(1), 21-32. https://doi.org/10.31328/jsed.v4i1.1769

ISSN 2615-6075 online; ISSN 2615-6946 print (C)WG Press, 2021

\section{INTRODUCTION}

Many measurement alternatives are applied to achieve better development. One of them is the human development index, which has been studied in depth by the United Nations Development Program since 1990 and is published regularly. Human development index is able to demonstrate the increasing quality of better human resources in human development. Increased human development index shows the indication of increased prosperity. Increased human development index represents the increasing number of population who can access development in obtaining basic needs, including income, health, education and so on evenly (Arisman, 2018; Fretes, 2017; Grubaugh, 2015; Panjawa, Samudro, \& Soesilo, 2018; Sulistyowati, Sinaga, \& Novindra, 2017; Vikash, 2019; Yuliani \& Saragih, 2014). Equity, especially the issue of inequality, is still one of the priorities in development. Uneven development will cause disparities. The gap of social and economy affects the ability of humans and is undesirable from the standpoint of welfare (Ghosh, 2019). 
The problem of development disparities faced by Indonesia is very complicated (Bappenas, 2008; Elia, Yulianto, Tiawon, Sustiyah, \& Indrajaya, 2020; Salqaura, Mulyo, \& Darwanto, 2019; Siburian, 2020; Soejoto, Fitrayati, Rachmawati, \& Sholikah, 2016). The complexity is considered to be diversity reflected in geographical, social, and economic differences. Complex issues are reduced by managing regional finances more efficiently. Elia et al. (2020) showed that research in new proliferation areas are mainly concerned with regional finances that are managed more efficiently by focusing on community economic activities. It can create investment opportunities and jobs based on the prominent regional product. Investment can increase employment and indirectly reduce poverty.

According to Siburian (2020), fiscal decentralization reduces regional income inequality. Autonomy encourages local governments in designing development programmes that match unique characteristics of a particular region and distributing more balanced resources within the region. Decentralization also encourages local governments to efficiently provide necessary public services. Ultimately, decentralization motivates local politicians to effectively allocate local public goods and services. Liu et al. (2017) added that effects of fiscal decentralization on regional inequality tend to be meaningful when they are measured from the expenditure side. At same the time, fiscal equalization efforts by sub-region government are shown by implementing equalization programs.

There are several development indicators that need to be considered to measure welfare. Soejoto et al. (2016) identified four indicators of regional development namely economic growth, fiscal decentralization, income inequality, and educational inequality. These indicators well describe the real conditions of public welfare. It means more attention is highly needed for fiscal decentralization, income inequality and inequality of education to see the success of economic development, not only the economic growth.

On the other hand, contradictions appear and complicate the development problem. Qiao et al. (2008) argued that fiscal decentralization leads to economic growth as well as significant increases in regional inequality. This is interpreted as trade-off between economic growth and regional equity in the design of fiscal decentralization policy.
There is increasing concern that the focus of activities development and growth is dominated by the Western and is compared to Eastern Indonesia (Hutajulu, Panjawa, Islami, \& Sugiharti, 2020; Nugraha, Wicaksono, \& Wijaya, 2017; Panjawa et al., 2018; Riphat, Setiawan, \& Damayanty, 2016). Based on the report about Evaluation of The Proliferation of Administrative Region in Indonesia by Bappenas (2008), the origin regions and the control regions consistently showed better results in all areas of focus (such as economic growth, regional fiscal management, public services and regional government personnel) compared to the new autonomous regions.

According to Tun (2008), Indonesia still has gaps in the human development dimensions over the past 15 years. Central Bureau of Statistics (2017) stated, in addition to the income gap, the gap in human development is also experienced by the Western and Eastern regions of Indonesia. The gap in human development is indicated by the index of human development that represents the quality of human resources. For five years, the low quality of human development in the Eastern Indonesia's provinces is still more significant compared to that in the Western Indonesia's provinces. It is even the lowest nationally.

Differences in the quality of human resources reflect the gap of human development. In Indonesia, the human development gap is shown by the significant difference in the value of the human development index between the West and East Regions. The problem of human development is one indicator of the emergence of a government policy called regional autonomy, as the implementation of Law No. 23 of 2014 replaces Law No. 32 of 2004, which previously replaced Law No. 22 of 1999.

The regional autonomy policy is expected to be able to improve the welfare of the people in an area (Moonti, 2019; Prabowo, Supriyono, Noor, \& Muluk, 2020). The policy of regional autonomy in Indonesia leads to regional proliferation. Regional proliferation means that the euphoria that has arisen since the implementation of regional autonomy has had a variety of impacts on society and the government. One of them is the demand for the formation of new regional governments (new regencies) from existing local governments. The readiness of an area is also crucial in dealing with regional autonomy policies and leading the regions that already have advanced 
economic structures (relatively rich regions) to be more capable and have high economic growth so that it impacts the welfare of the community. In contrast, the readiness of developing regions or relatively disadvantaged areas is considered low, and this leads to low economic growth.

The main focus of the new regency is the impact of decentralization policy directed at creating the level of regency/city government with new autonomy. The purpose of decentralization implies the benefits to promote more autonomous incomes. In other words, regencies/cities are a valid form of autonomy (Hariwan \& Swaningrum, 2015; Mcwilliam, 2011; Seymour \& Turner, 2002). The encouragement of regions to proliferate regions is expected to minimize disparities and improve social welfare (Jamal, 2017).

The implementation of regional autonomy in question is fiscal decentralization, which is the hope for regional governments. Fiscal decentralization refers to the transfer of authority and responsibilities from the central government to sub-national or regional governments. It is expected that the fiscal decentralization capacity of the region in terms of the fiscal capacity to be managed better, optimized and to be potentially and efficiently allocated under available resources. It leads each region to understand more on local preferences. With the ability of the region to be more independent in financial development, community welfare will increase, as measured by the achievement of the human development index (Madhu \& A.K., 2014; Mehmood, Sadiq, \& Khalid, 2010; Nursini, 2012; Pramartha \& Dwirandra, 2018).

Fiscal decentralization has led to economic growth and significant increase of inequality among regions (Qiao et al., 2008). The influence of decentralization becomes the attraction of discussion on inequality. Several previous studies related to growth, poverty and inequality with various results of relationship's contradiction among growth, poverty, and inequality are those by Benjamin et al. (2017), Breunig \& Majeed (2020), Hassan et al. (2015), Marrero \& Serven (2018), and Ngozi et al. (2020). According to Breuniq \& Majeed (2020), the policy of poverty reduction is unable to reduce the inequality, but is able to promote economic growth. Ngozi et al. (2020) stated that the existence of a inequality could detain sustainable growth. According to Brida et al. (2020), positive or negative relation between economic growth and inequality depends on the status of a region. In developed countries, the increase of economic growth could support the equal distributed income (convergency), while the increase of economic growth in poor and developing countries leads to the increase of income's consentration (divergency). On the other hand, according to Hassan et al. (2015) and Marrero \& Serven (2018), growth, proverty, and inequality have negative correlation with one another.

Human development has always been an essential issue in sustainable development planning and strategies (Sušnik \& van der Zaag, 2017). Hence, in human development, the improvement of the quality of human resources is needed. Human development is about the freedom to realize the full potential of every human life, not just for a few or the most, but from all lives in every corner of the world - now and in the future. Human development is for everyone, and that universalism is the core of the concept and framework of human development (Jahan, 2019; McNeill, 2007; Sharmila, 2013). Besides, improving the quality of human resources is a part of the efforts to build competent individuals. In the context of a nation, improving the quality of human resources includes human development both as individual beings and as resources for the nation's development. Both aspects are the primary concern of improving the quality of human resources to create welfare.

The low potential and quality of human resources are due to a large number of remote and developing areas with low education, infrastructure, health, and income, especially in Eastern Indonesia when compared to Western Indonesia. It is suspected that those factors lead to the findings of the most number of proliferation areas in Eastern Indonesia.

The abovementioned gaps motivate the researchers to empirically examine the effect development indicators, such as decentralization, economic growth, and poverty, on human development, as well as the comparison between origin and new (expanded) regions.

\section{RESEARCH METHOD}

This study uses a positivist perspective with a deductive approach. In the positivist perspective, researchers start their research from a causal relationship that logically refers to theory. In general, 
the positivism perspective uses a deductive approach. The development and affirmation of a theory that begin with abstract concepts and theoretical relationships and lead to more concrete empirical evidence are called the deductive approach (Neuman, 2011).

Secondary data with cross-section type are used in this research, including 232 regencies and cities in Eastern Indonesia in 2017. The data source in this study is from publication reports of Central Bureau of Statistics Indonesia, i.e. human development index report, Regency/City Gross Regional Domestic Product in Indonesia, Regency Government Statistics Book 2 (Bali, Nusa Tenggara, Kalimantan, Sulawesi, Maluku, Papua) and Regency/City Poverty Data and Information. This quantitative research uses econometrics methodology and regression analytical tool. According to Gujarati and Porter (2009), regression is a statistical analysis tool designed to measure the direction and magnitude of the influence of one or more variables on one or more dependent variables. The regression used in this study is the multiple linear regression. The model of the multiple linear regression equation, as follows:

$H D I_{i}=\beta_{0}+\beta_{1} F D P A D_{i}+\beta_{2} P O V R_{i}+\beta_{3} E G_{i}+\varepsilon_{i}$

where: $i$ is region; $\beta$ is a parameter (constants and coefficients); HDI is human development index; EG is economic growth showing the development of activities in an economy where the production of goods and services has increased and is used for assessing welfare; FDPAD is Fiscal Decentralization which shows the ratio of original regional revenue to total revenue; and POVR is level of poverty.

The use of dummy variables aims to determine differences in inequality between regions and the magnitude of the influence of each independent variable, specifically in the regression model in the origin and new regencies. In other words, the study empirically examines the relationship between human development inequality and development indicators, as well as the comparison on regions, i.e. between origin and new (expanded) regencies using regression with dummy variables as an analysis tool. According to Gujarati and Porter (2009), dummy variables are a tool for classifying data by dividing samples into various subgroups based on quality or attributes and explicitly making it possible to operate individual regressions for each subgroup (dummy variable techniques are flexible). To avoid the trap of dummy variables, the number of dummy variables is $\mathrm{k}-1=2-1=1$ (one dummy variable). The application of dummy variables in the regression equation (1) is as follows.

$$
\begin{aligned}
H D I_{i}= & \beta_{0}+\beta_{1} D 1_{i}+\beta_{2} F D P A D_{i}+\beta_{3} P O V R_{i}+ \\
& \beta_{4} E G_{i}+\beta_{5} D 1^{*} F D P A D_{i}+\beta_{6} D 1^{*} P O V R_{i}+ \\
& \beta_{7} D 1^{*} E G_{i}+\mu_{i}
\end{aligned}
$$

where: D1 is a dummy variable, has a value of 0 for the origin regency, and 1 for the other regions/ new regency (the area of post division of Law No. 22 of 1999, Law No. 32 of 2004 Law and No. 23 of 2014). It should be noted that the mapping regarding the new regency is indicated by regional laws based on the formation of autonomous regions in Indonesia from the publication of the Directorate General of Regional Autonomy of the Ministry of Home Affairs of the Republic of Indonesia. Besides Goodness of Fit, other underlying assumptions to support the analysis tools in this study include the normality test, heteroscedasticity test, and model specifications.

\section{RESULT AND DISCUSSION}

\section{Human Development Gap}

The inequality among regions and among socioeconomic groups in Indonesia is still is one of the important challenges in national development. At present, the gap among regions in Indonesia is considered relatively high, in particular gaps in human development between Western Indonesia and Eastern Indonesia. Furthermore, human development gaps also occur within the Eastern Indonesia regions.

Table 1 and 2 show the data of development indicators in the Eastern area of Indonesia in 2017. Several indicators are referred from human development, economic growth, decentralization and poverty. The data are arranged based on regions for the category of human development index.

Extremely high and high categories for development index were still dominated by cities (when compared with regency areas). The highest human development index was occupied by the city of Kendari with a score of 81.81. There were 53 regions classified as having extremely high and high development index, 3 regions categorized as having extremely high human development index (with the average of 81.98), and 50 regions grouped in the category of high (with the average of 73.92 for human development index). 
Table 1. Development Indicators in New Regions in Eastern Indonesia, 2017

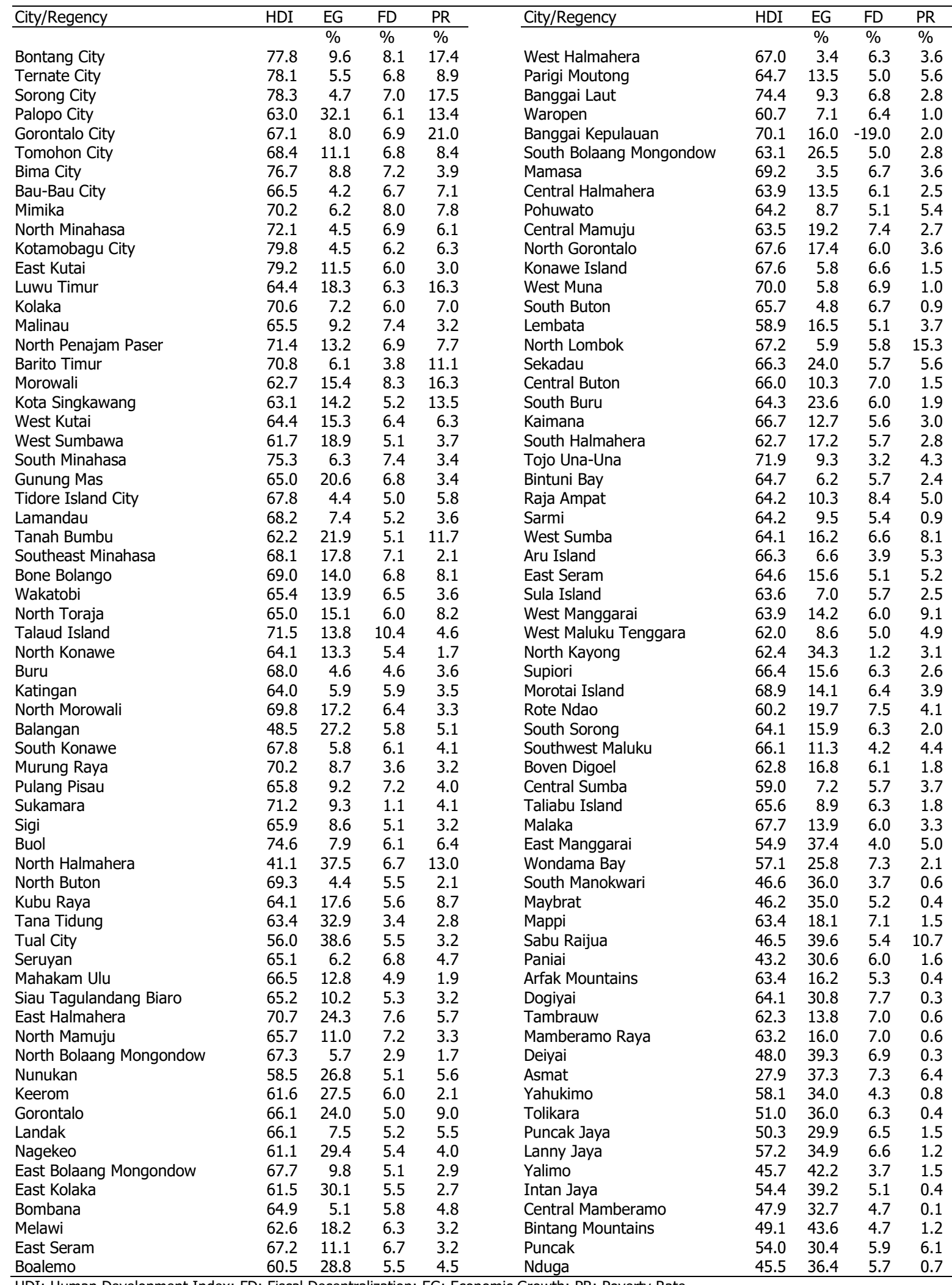

HDI: Human Development Index; FD: Fiscal Decentralization; EG: Economic Growth; PR: Poverty Rate 
Table 2. Development Indicators in Origin Regions in Eastern Indonesia, 2017

\begin{tabular}{|c|c|c|c|c|c|c|c|c|c|}
\hline City/Regency & HDI & EG & FD & PR & City/Regency & HDI & EG & FD & PR \\
\hline & & $\%$ & $\%$ & $\%$ & & & $\%$ & $\%$ & $\%$ \\
\hline Makassar City & 81.1 & 4.6 & 8.2 & 34.9 & Tanah Laut & 66.1 & 26.8 & 4.5 & 6.8 \\
\hline Ambon City & 81.8 & 5.0 & 6.4 & 11.6 & Kota Baru & 66.7 & 8.3 & 8.3 & 8.6 \\
\hline Palangka Raya City & 77.9 & 5.3 & 5.1 & 11.4 & Hulu Sungai Tengah & 74.1 & 8.4 & 6.9 & 7.5 \\
\hline Samarinda City & 80.2 & 6.7 & 5.9 & 21.6 & Banjar & 66.3 & 6.9 & 7.4 & 9.1 \\
\hline Banjar Baru City & 76.5 & 4.2 & 6.4 & 16.2 & Bantaeng & 66.7 & 16.7 & 4.4 & 10.7 \\
\hline Kupang City & 76.7 & 17.8 & 8.4 & 14.5 & Pangkajene And Islands & 70.7 & 9.9 & 5.1 & 12.2 \\
\hline Manado City & 79.5 & 5.2 & 0.7 & 19.6 & Nabire & 61.4 & 16.0 & 5.8 & 4.3 \\
\hline Pontianak City & 71.5 & 7.7 & 3.1 & 26.9 & Bulukumba & 72.0 & 5.9 & 6.8 & 14.3 \\
\hline Mataram City & 70.4 & 14.6 & 14.4 & 21.8 & Tana Toraja & 65.4 & 13.3 & 7.6 & 10.4 \\
\hline Pare-Pare City & 66.4 & 16.5 & 6.6 & 13.5 & Soppeng & 72.2 & 7.5 & 6.5 & 7.2 \\
\hline Bitung City & 72.9 & 6.6 & 6.2 & 12.4 & Ende & 64.9 & 12.2 & 5.2 & 4.9 \\
\hline Kutai Kartanegara & 67.3 & 16.2 & 6.6 & 10.6 & Fakfak & 63.9 & 21.3 & 6.8 & 5.0 \\
\hline West Kotawaringin & 69.1 & 5.0 & 4.1 & 11.8 & Bolaang Mongondow & 64.6 & 4.5 & 4.5 & 4.0 \\
\hline Biak Numfor & 79.7 & 3.6 & 7.0 & 12.4 & Yapen Island & 67.6 & 14.9 & 5.0 & 7.3 \\
\hline Enrekang & 67.3 & 9.7 & 7.3 & 10.0 & Bengkayang & 62.1 & 27.1 & 5.9 & 4.6 \\
\hline Pasir & 73.6 & 5.4 & 3.0 & 6.2 & Sambas & 69.1 & 5.2 & 6.0 & 6.2 \\
\hline Jayapura & 55.2 & 31.1 & 5.1 & 6.9 & Sumbawa & 62.1 & 23.6 & 3.3 & 8.3 \\
\hline Tabalong & 72.8 & 7.6 & 1.4 & 9.7 & Sinjai & 68.0 & 5.3 & 7.6 & 6.3 \\
\hline Bulungan & 66.8 & 12.6 & 7.5 & 6.4 & Ketapang & 59.6 & 21.7 & 4.9 & 5.1 \\
\hline Manokwari & 68.3 & 8.4 & 7.2 & 5.1 & Takalar & 68.7 & 3.8 & 5.1 & 10.7 \\
\hline Konawe & 64.7 & 18.2 & 5.0 & 7.7 & Majene & 66.1 & 26.0 & 7.1 & 7.2 \\
\hline North Barito & 65.8 & 15.3 & 6.8 & 5.3 & East Lombok & 67.1 & 25.4 & 6.4 & 11.2 \\
\hline Luwu & 67.9 & 14.4 & 8.2 & 7.5 & Central Lombok & 69.1 & 11.8 & 5.5 & 9.2 \\
\hline Banggai & 62.3 & 29.3 & 5.0 & 7.0 & Hulu Sungai Utara & 62.0 & 23.5 & 5.1 & 9.2 \\
\hline Tapin & 72.4 & 14.9 & 5.7 & 5.1 & East Sumba & 70.1 & 21.2 & 5.8 & 7.3 \\
\hline Merauke & 62.8 & 22.9 & 5.1 & 6.1 & Kapuas Hulu & 67.0 & 5.2 & 5.9 & 2.8 \\
\hline Maros & 68.4 & 14.3 & 7.6 & 14.1 & Bone & 66.1 & 8.0 & 6.7 & 2.8 \\
\hline North Luwu & 70.2 & 15.7 & 5.2 & 7.8 & Toli-Toli & 59.4 & 36.0 & 4.9 & 6.9 \\
\hline Gowa & 70.6 & 7.6 & 2.3 & 10.1 & Sorong & 70.1 & 9.8 & 6.5 & 5.6 \\
\hline Wajo & 67.8 & 6.1 & 5.7 & 8.6 & Sikka & 67.4 & 15.7 & 7.5 & 9.4 \\
\hline North Central Timor & 61.2 & 37.4 & 4.0 & 4.1 & East Flores & 71.2 & 8.1 & 6.0 & 5.0 \\
\hline Southwest Sumba & 64.5 & 13.5 & 4.9 & 4.5 & Kupang & 64.4 & 12.5 & 4.8 & 7.8 \\
\hline Belu & 65.0 & 16.7 & 4.9 & 6.3 & Jeneponto & 61.5 & 9.9 & 5.4 & 9.5 \\
\hline South Central Timor & 58.1 & 36.4 & 5.2 & 4.6 & Polewali Mandar & 64.1 & 14.2 & 6.3 & 99.6 \\
\hline Alor & 60.1 & 19.9 & 4.3 & 5.1 & Manggarai & 62.6 & 4.1 & 16.2 & 8.4 \\
\hline Jayawijaya & 62.8 & 18.4 & 6.4 & 5.6 & Pontianak/Mempawah Regency & 68.0 & 16.2 & 6.0 & 6.8 \\
\hline
\end{tabular}

HDI: Human Development Index; FD: Fiscal Decentralization; EG: Economic growth; PR: Poverty Rate

Furthermore, in terms of status, in the extremely high and high categories, there were 31 origin regencies (with the average of human development index 75.26) and 22 new regencies (with the average of 73.01). There are 151 regencies grouped in medium category for human development index (with average of 65.32). While it can be indicated that smaller numbers of origin area are calculated, there were as many as 71 regions (with human development index of 66.03) if being compared with new regencies with 80 regions (with average of human development index of 64.69). Moreover, the human development index for the low category was dominated by 28 regencies (with average of human 
development index of 51.53). Nduga regency was categorized as the region with the lowest category with index score of 27.87. In detail, there were two origin regions that are categorized as having the lowest human development index (with the average of 57.80) and 26 new regions (with average of 50.86). This condition was also experienced by origin and new regencies, in terms of status. For Statusbased comparison towards entire categories of human development, the human development index in new regencies was smaller than origin regencies. This shows the existence of Human Development Index (HDI) gap in Eastern Indonesia. In other words, human development in Eastern Indonesia is considered unequal.

Besides, the level of human development is not the determining factor for economic growth, fiscal decentralization and poverty. As displayed in Table 2, the region with the highest human development score did not always mean it had high economic growth and decentralization and lower poverty rate, and so did the regions with low human development index. In other words, a region has various levels of economic growth, fiscal decentralization and poverty rate in certain human development index. Nevertheless, regions with better human development index is aligned with high fiscal decentralization.

\section{Factors Affecting Human Development}

In addition to the popularity of the income gap problem, the problem of human development inequality also requires more attention in its development. Even after the era of the Millennium Development Goals (MDGs), the era of Sustainable Development Goals (SDGs) still raise the problem of inequality and human development. SDGs show that human development has always been an important issue in development planning and strategies. Dummy variable regression is one of the right approaches to answer the purpose of this study, which specifically discusses the identification of differences in the gap of human development in the origin region and expansion in Eastern Indonesia and the determinants of human development. The following is the results of dummy variable regression.

The goodness of fit test results based on Table 3 for simultaneous tests can conclude that the model used exists. It means that simultaneously independent variables in the study have turned away and have been influenced significantly by the human development index. These results based on $\mathrm{p}$-value of $F$ statistic of 0.0000 was smaller than $1 \%$. Moreover, the interpretation of the determinant coefficient (R2) showed a value of 0.6406 , which means that the variance variable independently in this study can explain the variables of human development index of $64.06 \%$, while the remaining $35.94 \%$ explained by other factors was not included in the model.

Table 3. Estimate Variable Affecting Human Development

\begin{tabular}{lcc}
\hline Variable & Coefficient & p value \\
\hline Constant (C) & 73.8736 & 0.0000 \\
Dummy (D1) & -3.7924 & 0.0931 \\
Fiscal Decentralization (FDPAD) & 0.1109 & 0.0062 \\
Poverty (POVR) & -0.3096 & 0.0000 \\
Economic growth (EG) & 0.4485 & 0.2207 \\
D1*FDPAD & -0.0940 & 0.0001 \\
D1*POVR & 0.1426 & 0.1686 \\
D1*EG & -0.3096 & 0.6169 \\
\hline
\end{tabular}

Goodness of Fit

$\mathrm{R} 2=0.641 ; \mathrm{F}$ statistic $=56.788$

Adjustment $R 2=0.629 ; p$ value $=0.000$

Diagnostics Test

Normality Test: Jarque-Bera $=4.2695 ; \mathrm{p}$ value $=0.118$

Heteroskedasticity Test: Harvey $=14.5117$, p value $=0.043$

It is worth noting that the number of observations in this study covers all regencies and cities in Eastern Indonesia except Nduga regency. It was not included in the observation because it was estimated to be biased. By not including outlier data, it is expected that the normal distribution would follow the regression analysis assumption. Therefore, the diagnostic test in the research requires fulfilling the normal residual distribution, homoscedasticity, and exact model specifications.

As displayed in Table 3, the regression results show the findings regarding the existence of a gap in human development between the origin regency and the new regency in Eastern Indonesia. The gap in human development between the two regions explains the differences in the quality of human resources. A significant human development gap between origin regency and new regency is reflected as the level of significance partially for $\mathrm{p}$-value of $\mathrm{t}$ statistic was 0.0931 , smaller than $10 \%$, and the coefficient on the dummy variable (D1). The $p$-value of t-statistic 0.0931 was smaller than $10 \%$, and the coefficient value was -3.7924 . The condition of the quality of human resources in the new regency was 
3.7924 lower than in the origin regency. This was caused by two factors, namely the condition where the development of underdeveloped regions was hampered by regions that have advanced or are backward (backwash effects) and the condition where the development of underdeveloped regions was driven by regions that were more advanced first. Therefore, because of the exacerbation of interregional social-economic development gaps, the effect of spread effects was smaller than backwash effects.

There are three indications of backwash effects that occurred in eastern Indonesia. First, excessive exploitation of natural resources from remote and developing areas. Second, the low potential and quality of human resources due to a large number of remote and developing areas with low education, infrastructure, health, and income. In other words, the quality of human resources in the origin regency tends to be better than the new regency. Third, the readiness of development in origin regions that have been arranged earlier and running well in terms of institutional, social, economic, political, and others in autonomy, while a new regency needs relatively more time to be autonomous. It is hoped that in the long run, the formation of new regions would be able to overcome gaps in various aspects.

This finding is in agreement with Bappenas (2008) findings which showed that the economic performance of new autonomous regions is lagging in comparison to origin regions and other regions. This is generally due to limited human resources and inadequate government support for the economy through public investment.

In Table 3, the regression results show findings that support regional autonomy for equity and welfare in origin and new regencies in Eastern Indonesia. Partially fiscal decentralization has a significant positive effect on human development index in origin and new regencies. This was indicated by the $p$-value of fiscal decentralization of origin regencies by 0.0062 and new regencies by 0.0001 smaller than $1 \%$. The enactment of regional autonomy through the instrument of fiscal decentralization turned out to have a positive impact on regional development, particularly in improving the quality of human resources in origin and new regencies. The implication is that origin and new regencies will better understand local preferences with fiscal decentralization policies and be able to increase the ability of regions to manage fiscal capacity wisely, optimizing and allocating the potential of their resources efficiently. Besides, through the measurement of fiscal decentralization with the ratio of regional own-source revenues to total revenues that have a significant positive impact, this becomes evidence for regions to become more independent. Fretes (2017) added that increasing Regional Development Budget (APBD) input through the potential of Locally-generated Revenue (PAD) will make the region's ability to finance capital expenditures larger so that it can increase outcomes in the form of increasing the human development index. Efforts to increase PAD must also look at regional resources and capabilities so that there is no trade-off where the passionate desire to boost PAD becomes a disincentive that kills regional economic (investment) potential.

The quality improvement of local government apparatus and services to the public and private sector in having greater benefits is a logical consequence of wise budgeting management. Properly-managed budget allocation provides opportunity and assurance to improve production in the private sector. Private sector is expected for providing contribution to local government in terms of the expansion of job opportunities that will become one of the sources of PAD (Putu, Maryunani, Fajri, \& Budi, 2019). Therefore, the increase of PAD can be followed with the adjustment of regional expenditures, designated for the improvement of human resource development in the field of education, health and per capita income, to meet the equal human development in the entire region.

Table 3 shows that poverty reduction does not significantly influence the increase in the human development index in the new regency. Although it does not have a substantial impact, poverty alleviation indicates a positive thing in increasing the human development index, and ultimately the government continues to strive to improve the welfare of the community. Different things happen in the origin regency, where reducing poverty can improve the quality of human resources. Therefore, it can be concluded that poverty reduction has a significant adverse effect on the human development index in the origin regency. Pro-poor government programs and policies are expected to improve the quality of human resources. Provision of stimulants, assistance, and facilities through programs of basic 
needs, such as education, health, and economy, is expected to improve community welfare. This, of course, also must be supported by institutional improvement (good governance). Sulistyowati et al. (2017) said that picking up part of government and household computer schemes has an impact on the human development index. Increased employment opportunities, increased community capacity, and poverty alleviation are goals in human development. Economic and human development goals can be achieved by increasing the capacity of education, health, and community income simultaneously. Schemes can be offered by increasing education spending to increase the workforce and improve physical models through improving health and infrastructure spending. With an increase in physical capital and labour expected to increase Gross Domestic Product (GDP), per capita income, and human development index.

On the other hand, an increase in GDP is expected to increase people's income and encourage people to increase household spending on education, health, and other expenses. Government expenditure and household expenditure are expected to reduce poverty. Decreasing the number of poor people will increase the index of human development.

The last discussion shows that the statistical problem of economic growth in the origin and new regions were 0.2207 and 0.6169 , which was higher than any significance level. The conclusion for the test results shows that economic growth had no significant effect on the human development index both in origin and new regencies. The result becomes a new finding that sustainable economic growth needs to be done in origin and new regencies in Eastern Indonesia, so the sustainable economic growth is not only oriented to the high value of economic growth through resource exploitation and consumption alone. This research also indicates that economic growth does not affect the quality improvement of human resources due to the low economic activity in Eastern Indonesia and concentrated economic activity in Western Indonesia. The results of this study are not in line with research conducted by Fretes (2017) in which economic growth should be able to influence an increase in output capital expenditure as a whole, not only from government spending but also investment from the private sector. Economic growth will increase the revenue budget obtained by the government, followed by the addition of capital expenditure allocations. Increased output of capital expenditure from the government and the private sector is the result of increased economic growth and also influence the increase in the human development index.

\section{Research Implication}

The findings provide some support for the reduction of human development gap in origin and new regencies in Eastern Indonesia. This study provides the implications as follows.

First, development programs should reconsider the alleviation of poverty and economic growth that has insignificant impacts in the area of origin and expansion. This is particularly in terms of the quality improvement in development trough efforts to meet equal human development in every region. Hence, the economic growth will be qualified and sustained. The specific purpose is to distribute the growth evenly, particularly for qualified human development, without only exploiting the resources.

Secondly, the government should improve the management quality for regencies and cities of origin and expansion in terms of fiscal decentralization and regional autonomy policy. Budgeting management takes firm budgeting structure, since good budgeting governance in decentralization is probably not aligned with proper budgeting structure. The combination of fiscal decentralization between budgeting governance and structure should be balanced with the efforts of enhancing the revenue from internal sources (Original Local Government Revenue) and expenditures. Aside from reducing the dependency on development funding from the central government, increased local revenue can be aligned with the local expenditures, particularly on human resources quality improvement, in the field of education, health and per capita income, to meet equal human development in every region.

According to Elia et al. (2020), regional finances that are managed more efficiently by focusing on community economic activities can create investment opportunities and create jobs based on the prominent regional product. This is supported by the opinion of Siburian (2020) that autonomy encourages the local governments in designing development programs that match unique characteristics of a particular region and distributing more balanced resources within it. Decentralization also encourages 
a local government to efficiently provide public services in need. Ultimately, decentralization motivates local politicians to effectively allocate local public goods and services. Liu et al. (2017) added that effects of fiscal decentralization on inequality tend to be significant when it is measured from the expenditure side. These findings may help us to understand that not only government expenditure can reduce inequality. Results of the studies provide further support for measure of fiscal decentralization from government revenue side in reducing inequality. Fiscal Decentralization shows the ratio of original regional revenue to total revenue.

Thirdly, according to Bappenas (2008) it is necessary for a preparatory period for transfer of personnel and for local economic and governance infrastructure to be established before proceeding with administrative division so that the new autonomous regions have better development performance. One indisputable prerequisite is the equitable division of economic potential for new autonomous regions to develop on par with the parent regions. In the short-term, changes in the pattern of personnel and development expenditure are necessary to stimulate local demand for goods and services. Full support must be provided for the development of agriculture as an economic base for new autonomous regions. Moving forward, there is an urgent need for fundamental changes in the law governing the division and establishment of new autonomous regions.

\section{CONCLUSION AND SUGGESTION}

Measurements that use the human development index can show improvements in the quality of human resources better in human development. Increased human development index shows the indication of increased prosperity. Results indicate that there is a difference in the human development index between origin and new regencies in eastern Indonesia. The human development index in the new regency is lower than in the origin regency. Thus, according to Myrdal Theory, the worsening disparities in human development between regions is due to the tremendous impact of backwash effects that occur in Eastern Indonesia. In origin and new regencies, fiscal decentralization had a significant positive effect on improving the quality of human development. Different results in origin and new regencies indicate that economic growth does not significantly influence the quality of human development. Poverty reduction occurring in the origin regency had a significant effect on improving the quality of human development, but did not affect the new regency.

From the overall results, the role of government in human quality development is still needed. Many more various studies related to sustainable development are required in order to find the right formula to be applied in various regional conditions. The fiscal decentralization policy by the government should take into account a good combination of budget governance and budget structure in increasing local revenue and expenditure for better and more balanced human development in the origin and new regions.

\section{REFERENCES}

Arisman, A. (2018). Determinant of human development index in ASEAN countries. Signifikan: Jurnal Ilmu Ekonomi, 7(1), 113-122. https://doi.org/10.15408/sjie.v7i1.6756

Central Bureau of Statistics (2017). Indeks Pembangunan Manusia 2017. Jakarta: Badan Pusat Statistik.

Bappenas. (2008). Evaluation of the proliferation of administrative region in Indonesia, 2001-2007. Jakarta: BRIDGE, Bappenas-UNDP. Retrieved from https://www.undp.org/content/dam/ indonesia/docs/pemekaran_EN.pdf

Benjamin, D., Brandt, L., \& McCaig, B. (2017). Growth with equity: income inequality in Vietnam, 2002-14. Journal of Economic Inequality, 15(1). https://doi.org/10.1007/s10888-016-9341-7

Breunig, R., \& Majeed, O. (2020). Inequality, poverty and economic growth. International Economics, 161 , 83-99. https://doi.org/10.1016/j.inteco.2019.11.005

Brida, J. G., Carrera, E. J. S., \& Segarra, V. (2020). Clustering and regime dynamics for economic growth and income inequality. Structural Change and Economic Dynamics, 52, 99-108. https://doi.org/https://doi.org/10.1016/j.strueco. 2019.09.010

Elia, A., Yulianto, Y., Tiawon, H., Sustiyah, S., \& Indrajaya, K. (2020). Government expenditure and poverty reduction in the proliferation of new administrative areas of Central Kalimantan, Indonesia. Journal of Socioeconomics and Development, 3(2), 145. https://doi.org/10.31328/jsed.v3i2.1410 
Fretes, P. N. De. (2017). Pengaruh dana perimbangan, pendapatan asli daerah, dan pertumbuhan ekonomi terhadap indeks pembangunan manusia di Kabupaten Kepulauan Yapen. Jurnal Akuntansi \& Ekonomi FE. UN PGRI Kediri, 2(2), 1-33. Retrieved from https://ojs.unpkediri.ac.id/index.php/akuntansi/ar ticle/view/864

Ghosh, J. (2019). The uses and abuses of inequality. Journal of Human Development and Capabilities, 20(2), 181-196. https://doi.org/10.5117/tvgend2013.1.scot

Grubaugh, S. G. (2015). Economic growth and growth in human development. Applied Econometrics and International Development, 15(2), 5-16. https://doi.org/10.1007/978-3-64240826-7

Gujarati, D. N., \& Porter, D. C. (2009). Basic Econometrics (5th ed.). New York: McGraw-Hill Education.

https://books.google.co.id/books/about/Basic_Eco nometrics.html?id=6l1CPgAACAAJ\&redir_esc=y

Hariwan, P., \& Swaningrum, A. (2015). Analisis indeks pembangunan manusia pada 5 wilayah hasil pemekaran di Jawa Barat. Jurnal Ekonomi Kuantitatif Terapan, 8(1), 72-82. Retrieved from https://ojs.unud.ac.id/index.php/jekt/article/view/ 16496

Hassan, S. A., Zaman, K., \& Gul, S. (2015). The Relationship between growth-inequality-poverty triangle and environmental degradation: unveiling the reality. Arab Economic and Business Journal, 10(1), https://doi.org/10.1016/j.aebj.2014.05.007

Hutajulu, D. M., Panjawa, J. L., Islami, F. S., \& Sugiharti, R. R. (2020). Determinan pertumbuhan ekonomi berkelanjutan wilayah induk dan pemekaran di Kawasan Timur Indonesia. Jurnal Ekonomi Dan Bisnis, 23(2), 263-284. https://doi.org/10.24914/jeb.v23i2.3293

Jahan, S. (2019). Human development and universalism: from ideas to policies. Journal of Human Development and Capabilities, 20(2), 233-250. https://doi.org/10.1080/19452829.2019.1574726

Jamal, A. (2017). Geographical economic concentration, growth and decentralization: empirical evidence in Indonesia. Jurnal Ekonomi Pembangunan, 18(2), 142-158. https://doi.org/10.23917/jep.v18i2.2786

Liu, Y., Martinez-Vazquez, J., \& Wu, A. M. (2017). Fiscal decentralization, equalization, and intra- provincial inequality in China. International Tax and Public Finance, 24(2), 248-281. https://doi.org/10.1007/s10797-016-9416-1

Madhu, S., \& A.K., G. (2014). The Relationship between financial development indicators and human development in India. International Journal of Social Economics, 41(12), 1194-1208. https://doi.org/10.1108/IJSE-11-2013-0268

Marrero, G. A., \& Serven, L. (2018). Growth, Inequality, And Poverty: A robust relationship? (No. 8578). World Bank Working Paper. Washington, DC. Retrieved from http://documents1.worldbank.org/curated/en/248 621536264773958/pdf/WPS8578.pdf

McNeill, D. (2007). Human development: the power of the idea. Journal of Human Development, 8(1), 5-22. https://doi.org/10.1080/14649880601101366

Mcwilliam, A. (2011). Marginal governance in the time of pemekaran: case studies from Sulawesi and West Papua. Asiean Journal of Social Science, 39, https://doi.org/10.1163/156853111X565869

Mehmood, R., Sadiq, S., \& Khalid, M. (2010). Impact of fiscal decentralisation on human development: a case study of Pakistan. The Pakistan Development Review, 49(4), 513-530. Retrieved from https://www.jstor.org/stable/41428672?seq=1

Moonti, R. M. (2019). Regional Autonomy in Realizing Good Governance. Substantive Justice International Journal of Law, 2(1), 43. https://doi.org/10.33096/substantivejustice.v2i1.3 1

Neuman, W. L. (2011). Sosial Research Methods: Quantitative and Qualitative Approaches. Boston: Pearson Education, Inc. https:// books.google.co.id/books?id=rKL9lgWN_1gC\&q

Ngozi, B., Gershon, O., \& Ogundipe, A. (2020). Comparative investigation of the growth-povertyinequality trilemma in Sub-Saharan Africa and Latin American and Caribbean Countries. Heliyon, 6 , 1-11. https://doi.org/10.1016/j.heliyon.2020.e05631

Nugraha, Q. S., Wicaksono, A. D., \& Wijaya, N. S. (2017). Regional disparity level at West Papua Province. International Journal of Environmental and Agriculture Research, 3(8), 75-81. https://doi.org/10.25125/agriculture-journalijoear-aug-2017-9

Nursini. (2012). Implementation of fiscal decentralization in Indonesia: 2001-2009. Jurnal 
Ekonomi Pembangunan, 13(1), 2001-2009. Retrieved from http://journals.ums.ac.id/ index.php/JEP/article/view/179

Panjawa, J. L., Samudro, R., \& Soesilo, M. (2018) Regional economic disparities in eastern indonesia and determinants: comparative analysis of origin district and new district. Regional Science Inquiry, $X(1)$, 117-124. Retrieved from https://ideas.repec.org/a/hrs/journl/vxy2018i1p11 7-124.html

Prabowo, P. A., Supriyono, B., Noor, I., \& Muluk, M. K. (2020). Special autonomy policy evaluation to improve community welfare in Papua Province Indonesia. International Journal of Excellence in Government, 1-17. https://doi.org/10.1108/ijeg06-2019-0011

Pramartha, I. M. A., \& Dwirandra, A. A. N. B. (2018). Pengaruh desentralisasi fiskal, belanja modal, dan investasi swasta terhadap indeks pembangunan manusia. E-Jurnal Akuntansi, 22(3), 2458-2482. https://doi.org/10.24843/EJA.2018.v22.i03.p30

Putu, P. I. B., Maryunani, Fajri, A. C., \& Budi, S. D. (2019). The implications of fiscal decentralization and budget governance on economic capacity and community welfare. Foresight, 21(2), 227249. https://doi.org/10.1108/FS-05-2018-0052

Qiao, B., Martinez-Vazquez, J., \& Xu, Y. (2008). The tradeoff between growth and equity in decentralization policy: China's experience. Journal of Development Economics, 86(1), 112128.

https://doi.org/10.1016/j.jdeveco.2007.05.002

Riphat, S., Setiawan, H., \& Damayanty, S. A. (2016). Causality analysis between financial performance and human development index: a case study of provinces in Eastern Indonesia. Kajian Ekonomi Dan Keuangan, 20(3), 231-240. https://doi.org/10.31685/kek.v20i3.195

Salqaura, S. S., Mulyo, J. H., \& Darwanto, D. H. (2019). The influence of fiscal policy on agriculture sector in Java island. Agro Ekonomi, 29(2), 173-184. https://doi.org/10.22146/ae.35044

Seymour, R., \& Turner, S. (2002). Otonomi daerah: Indonesia's decentralisation experiment. New Zealand Journal of Asian Studies, 4(2), 33-51.
Retrieved from https://citeseerx.ist.psu.edu/viewdoc/download?d oi $=10 \cdot 1 \cdot 1 \cdot 628.170 \&$ rep $=$ rep $1 \&$ type $=p d f$

Sharmila, G. (2013). The governance dimension of human development. Humanomics, 29(4), 240259. https://doi.org/10.1108/H-03-2013-0015

Siburian, M. E. (2020). Fiscal decentralization and regional income inequality: evidence from Indonesia. Applied Economics Letters, 27(17), 1383-1386. https://doi.org/10.1080/13504851.2019.1683139

Soejoto, A., Fitrayati, D., Rachmawati, L., \& Sholikah, N. (2016). Typology of regional economic development pattern. International Journal of Applied Business and Economic Research, 14(13), 9493-9505. Retrieved from https://serialsjournals.com/abstract/27493_46ady_soejoto.pdf

Sulistyowati, N., Sinaga, B. M., \& Novindra. (2017). Impacts of government and household expenditure on human development index. Journal of Economics and Policy, 10(2), 412-428. https://doi.org/10.15294/jejak.v10i2.11305

Sušnik, J., \& van der Zaag, P. (2017). Correlation and causation between the UN Human Development Index and national and personal wealth and resource exploitation. Economic ResearchEkonomska Istrazivanja, 30(1), 1705-1723. https://doi.org/10.1080/1331677X.2017.1383175

Tun, L. M. (2008). An empirical investigation of relationships between Official Development Assistance (ODA) and human and educational development. International Journal of Social Economics, 35(3), 202-221. https://doi.org/10.1108/03068290810847879

Vikash, V. (2019). Human development index and gross national happiness indices: a conceptual study. Advances In Management, 12(1), 62-63. Retrieved from https://www.worldresearchersassociations.com $/ \mathrm{m}$ ngmntcurrissue/10.pdf

Yuliani, T., \& Saragih, N. (2014). Determinan pembangunan manusia di kabupaten/kota Provinsi Jawa Tengah. Jejak, 7(1), 60-72. https://doi.org/10.15294/jejak.v7i1.3843 